\title{
完全弾塑性モデルの地震応答の片寄り \\ ASYMMETRY OF SEISMIC RESPONSE OF ELASTO-PLASTIC MODEL
}

\author{
丸橋 奈々子*, 市之瀬 敏勝** \\ Nanako MARUBASHI and Toshikatsu ICHINOSE
}

\begin{abstract}
This paper summarizes a study that aim to clarify the relation between the asymmetric response of the SDOF systems and the ground motion characteristics. The asymmetric response is affected by the ground acceleration more than the ground velocity. Rigid-Plastic Response Spectrum, which is newly defined as the relation between the base shear forces and maximum deformation of the rigid-plastic model, is useful to evaluate the effect of the ground motion on the asymmetric response of the elasto-plastic model.
\end{abstract}

Keywords : Asymmetric response, Rigid-Plastic Model, Groud Acceleration, Ground Velocity, Elasto-Plastic Model, Rigid-Plastic Response Spectrum 応答の片寄り, 剛塑性モデル, 地動加速度, 地動速度, 完全弾塑性モデル, 剛塑性応答スペクトル

\section{1.はじめに}

Capacity Spectrum Method ${ }^{1)}$ は, 地震時の建物の応答を知るための 主流な予測法の一つであり，限界耐力計算法 ${ }^{2)}, \mathrm{ATC}-40^{3)}$ などで用 いられている。この手法は 1 質点系の弾性応答に基づく予測法であ るが, 実際の弾塑性応答では, 何らかの影響で, 応答が片方向に進 み，予測值が大きく異なってしまうことがある。例えば免震建築物 に Capacity Spectrum Methodを適用すると，このような応答の片寄り によって免震層の変位が過大となり, 上部構造と下部構造が衝突す る危険性がある。

塑性変形の片寄りは, 秋山ら ${ }^{4)}$, 向井 $5^{5)}$, 石岡 ${ }^{6)}$ の研究で扱わ れているが，いずれも，地震動のどのような性質が片寄りに影響を 及ぼすかを追求していない。経験的に, 海洋型地震よりも直下型地 震の方が片寄りを生じやすいと認識されているのみで, これまで片 寄りの原因は明確にされずにいた。平成 17 年 6 月に交付されたエネ ルギー法”においても, 大きな塑性変形を生じるような建築物は適 用外となっている。

筆者らは文献 ${ }^{8)}$ で, 弾性域を持たず単純な剛塑性復元力特性 ${ }^{97}$ の 1 質点系モデルと, 単純な地動波形を用いて, 地動加速度の片寄り と応答の片寄りを比較し，両者には密接な関係があることを示した。 本論文では，実地震動にも適用できるような理論を展開するため, 実地震動に見られる地動加速度, 地動速度の片寄りのうち, どちら が応答の片寄りに影響を及ぼすかを単純な地動波形により検討した。
また, 地震動の片寄りを定量化し, 応答との比較を行った。最後に, 実地震動が建物の応答の片寄りに与える影響を表す指標として何が 適当であるかを検討した。

\section{2. 解析モデル}

解析モデルは図 1(a) に示すような質量 $m$ の一質点系モデルとした。 減衰は考慮しない。塑性変形の片寄りのみに着目するために, 剛塑 性 (図 1(b)) の復元力特性を用いた。また実際の建物との比較のため, 免震建物もしくは鉄骨造建物を想定した完全弾塑性モデル (図 1(c)) も用いた。完全弾塑性モデルの初期剛性を $K$ としたとき，初期周期 $T=2 \pi \sqrt{m / K}$ が $0.2 \mathrm{~s}$ ，または $0.6 \mathrm{~s}$ となるように $K$ を求めた。

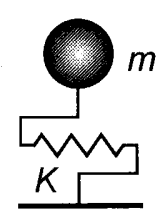

(a)

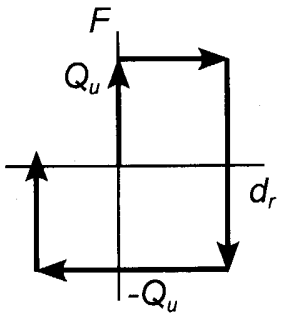

(b) 剛塑性モデル

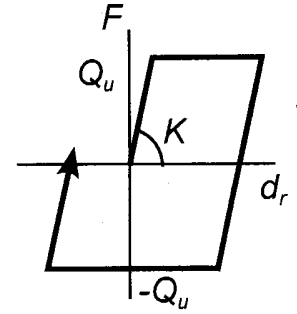

(c) 完全弾塑性モデル
* 名古屋工業大学大学院 大学院生 - 修士 (工学)

** 名古屋工業大学大学院 教授·工博
Graduate Student, Nagoya Institute of Technology, M. Eng.

Prof., Nagoya Institute of Technology, Dr. Eng. 


\section{3. 入力地震動}

応答解析の前段階として, PEER Strong Motion Database ${ }^{(0)} よ り$ 得ら れる全地震動記録 2715 波 (上下動を除く) を対象とし, 実際の地震 動がどの程度片寄りを持っているかを調べる。横軸に最大加速度の 絶対值を, 綎軸に正負の最大值の比率 (片寄り比率) をプロットした 結果を図 2(a) に示す。同様に地動速度の片寄り比率を図 2(b) に示す。 図中の破線は回帰直線を表す。

最大加速度が $6 \mathrm{~m} / \mathrm{s}^{2}$ 以上の地震動では，片寄り比率が 2 を超えるも のが $11 \%$ を占めた。また最大速度が $0.8 \mathrm{~m} / \mathrm{s}$ 以上の地震動では片寄り 比率が 2 を超えるものが $15 \%$ を占めた。なお，図中の 印，○印の 地震動は 7 章で使用する。

しかし，実地震動をそのまま使用すると，応答の片寄りの原因究 明は複雑になる。そこで, 4 〜 章では, 単純な地動波形を用いて 応答解析を行う。加速度に片寄りがある単純波の時刻歴を図 3 に示 す。(a) (c) は地動加速度, 速度, 变位である。地動加速度の片寄 りの比率 (図中 $a: b$ の比率) は $11.1 .5,2.5$ とし，それぞれ $\mathrm{Al} ＼textrm{A} 1.5$,
A2.5 と呼ぶ。図2(a) からわかるように，A1，A1.5 が一般的な片寄り の比率に，A2.5 は大きく片寄る場合の比率に対応している。地動加 速度の片寄りの影響のみ抽出するため, 図 3(b), (c) の地動速度, 変 位は正負で最大值が等しくなるように設定した。ただし，最大加速 度を一定としたため，片寄り比率が大きくなるにつれ，地動速度， 変位の最大值は小さくなる。

同様に, 地動速度のみに片寄りがある単純波の時刻歴を図4に示す。 片寄りの比率は図3 の単純波と同梯とし，V1，V1.5，V2.5 とした。

各単純波の $10 \%$ 減衰の弾性加速度 - 弾性変位応答スペクトル関係 (Demand Spectrum) を図 5 に示す。特に図 5(a) では片寄りの比率が大 きくなるとスペクトルは著しく小さくなる。

\section{4. 地動加速度に片寄りのある単純波を入力したときの応答}

4.1 剛塑性モデル

剛塑性モデルに A1，A1.5，A2.5を入力したときのベースシア係数 $C_{b}$ と最大変位の関係を図 6(a) に示す。正負両方向の最大値を示し，

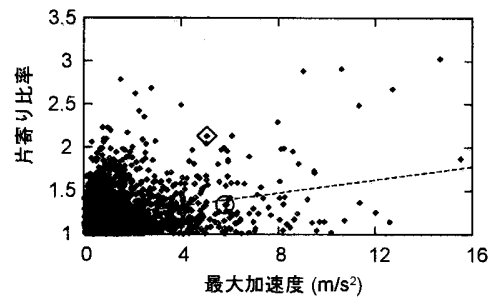

(a) 地動加速度

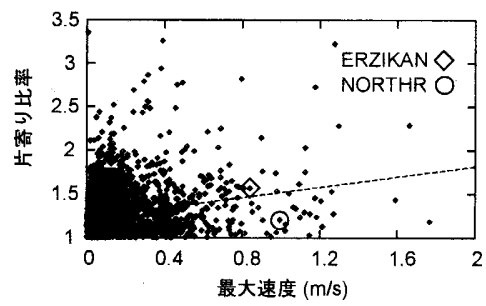

(b) 地動速度

図 2 地震動の片寄り比率

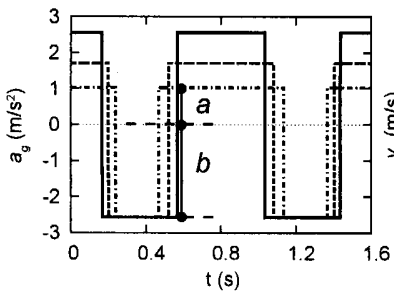

(a) 地動加速度

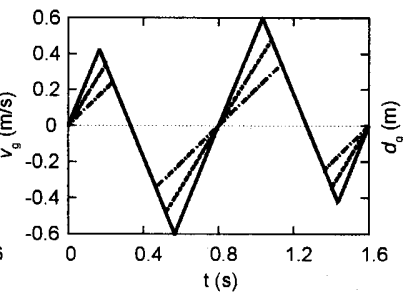

(b) 地動速度

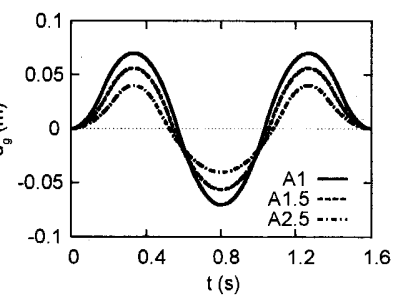

(c) 地動変位

図 3 地動加速度に片寄りのある単純波の時刻歴

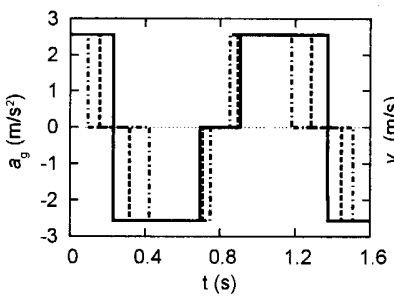

(a) 地動加速度

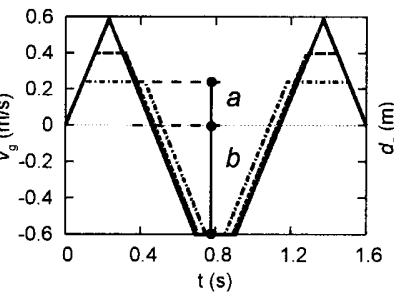

(b) 地動速度

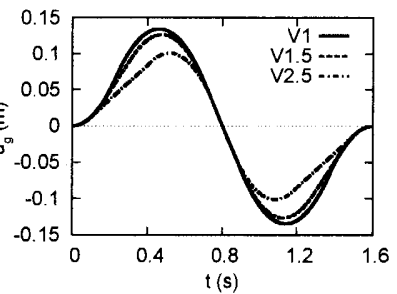

(c) 地動変位

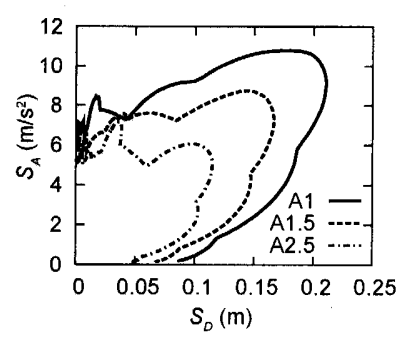

(a) 地動加速度の片寄る単純波

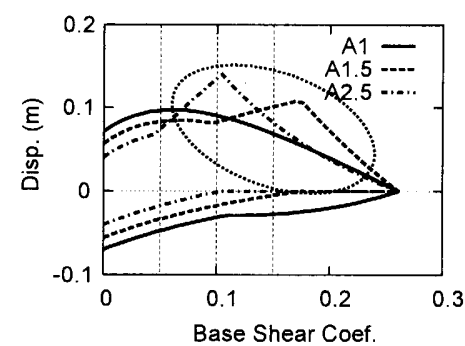

(a) 剛塑性

図4＼cjkstart地動速度に片寄りのある単純波の時刻歴

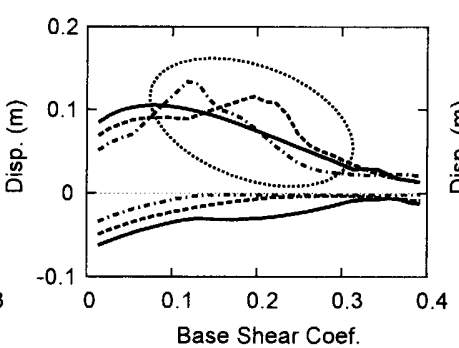

(b) 完全弾塑性 $(T=0.2 \mathrm{~s})$

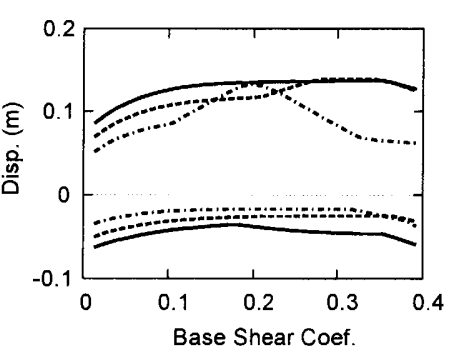

(c) 完全弾塑性 $(T=0.6 \mathrm{~s})$

図 6 ベースシア係数一最大変位関係 (地動加速度の片寄る単純波)

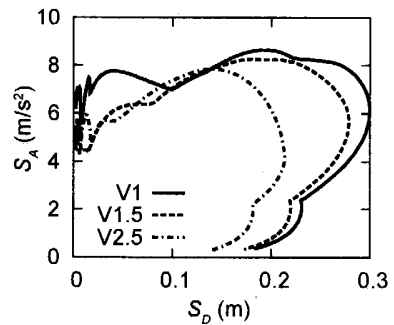

(b) 地動速度の片寄る単純波

図 5 Demand Spectrum 減衰 $10 \%$ )

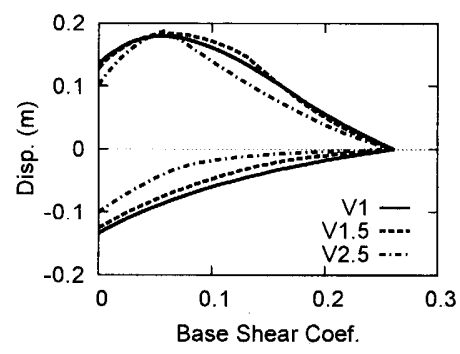

(a) 剛塑性

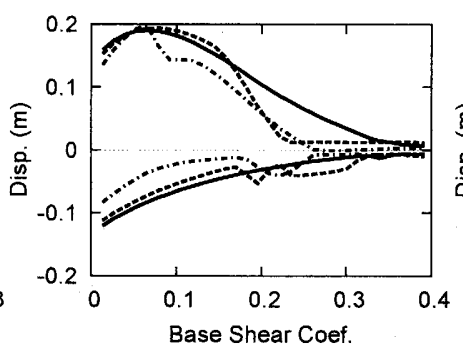

(b) 完全弾塑性 $(T=0.2 \mathrm{~s})$

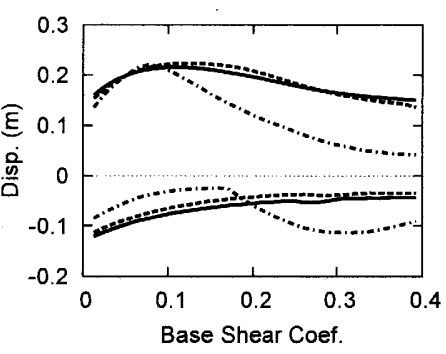

(c) 完全弾塑性 $(T=0.6 \mathrm{~s})$

図 7 ベ一スシア係数一最大变位関係 (地動速度の片寄る単純波) 
応答の片寄りを表す。

$\mathrm{A} 1$ を大力した場合, 正方向の最大変位は負方向の $1 \sim 3$ 倍程度 となり, 若干の片寄りが見られたが, 少なくとも正負両方向に変位 が生じたという意味では片寄りの少ない応答となった。一方, A1.5, A2.5 を入力した場合, $C_{b}$ の増加に伴い正方向の最大変位が増加し, それぞれ $C_{b}=0.1,0.18$ で大きく正方向に片寄り, 変形も最大值をと り, $C_{b}>0.1,0.18$ の領域では, 負方向の変位がゼロになった。つま り変形は正方向のみに生じた。 A $1.5, \mathrm{~A} 2.5$ は $\mathrm{A} 1$ よりも最大速度と Demand Spectrum が小さいにも関わらず (図 3(b), 図 5(a) 参照), $C_{b}$ によっては, $\mathrm{A} 1$ の変位を上回った (図 6(a) の破線に囲まれた部分)。 特に $\mathrm{A} 2.5$ の最大地動速度は $\mathrm{A} 1$ の $1 / 2$ 程度であるが, $C_{b}=0.1$ では正 方向の最大相対変位は $\mathrm{A} 1$ を大幅に上回った。地動速度は地震動の 破壊力を表す簡単な指標の一つとして挙げられるが, 実際には, こ のような地動速度と応答変位の逆転があり得る。Capacity Spectrum Method に用いる Demand Spectrum( 図 5(a)) にも同様のことが言える。

4.2 完全弾塑性モデル

完全弾塑性モデル $(T=0.2 \mathrm{~s}, 0.6 \mathrm{~s})$ のベースシア係数 $C_{b}$ と正負の 最大変位の関係を図 6(b), (c) に示す。図 6(b) の $T=0.2 \mathrm{~s}$ モデルは図 6(a)の剛塑性モデルとよく似た結果となり, A1.5, A2.5 の変位が A1 の変位を上回った (図 6(b) の破線に囲まれた部分)。これは，周期の 短い $T=0.2 \mathrm{~s}$ モデルは $T=0.6 \mathrm{~s}$ と比べ降伏変形が小さいため, 塑性変 形が支配的となったためである。

図 6(c) の $T=0.6 \mathrm{~s}$ モデルは, A1.5, A2.5 の応答に, 図 6(a), (b) の ような顕著な片寄りは見られず, $\mathrm{A} 1$ の変位を上回ることはなかった。 しかし, 図6(a)の剛塑性モデルの結果を横に引き延ばしたようなグ ラフとなり，剛塑性モデルと片寄りの傾向は似ているといえる。つ まり, 剛塑性モデルの片寄りは完全弾塑性モデルの片寄りを表して いるといえる。

\section{5. 地動速度に片寄りのある単純波を入力したときの応答}

剛塑性モデルと完全弾塑性モデル $(T=0.2 \mathrm{~s}, 0.6 \mathrm{~s})$ に V1, V1.5, $\mathrm{V} 2.5$ を入力したときのベースシア係数 $C_{b}$ と正負の最大変位の関係を 図 7(a)〜 (c) に示す。(a)〜 (c) いずれのモデルも，V1.5，V2.5に対 する応答は V1 とほぼ同じ形状となり，質点の変位が極端に片寄るこ とはなかった。図 6(a)，(b) の破線で囲まれた部分では，地動加速度 の片寄りによって忘答が片寄り，大きく変形したが，図 7(a)〜 (c) で は,このような傾向は見られなかった。つまり, 地動速度の片寄りは, 剛塑性モデルと完全弾塑性モデルの応答の片寄りにほとんど影響を 与えないことがわかる。図7(a), (b) では, 変位の大きさもほぼ同じ で, 地動変位の小さいV2.5がわずかに他より小さかった。図7(c)では, $C_{b}$ が大きい範囲で V2.5 の変位が小さかっった。 V1, V1.5, V2.5の応 答の大小関係は, Demand Spectrum(図 5(b)) の大きさに対応している。 図 4(b) とは逆に, 正方向の地動速度を $0.6 \mathrm{~m} / \mathrm{s}$ 一定とし, 負方向の速 度を減らした場合でも，ほぼ同様の結果が得られた。

\section{6. 地動加速度の片寄りと応答の片寄りの相関性}

4，5章より，地動速度の片寄りよりも地動加速度の片寄りの方が 応答の片寄りに及ぼす影響が大きいことがわかったが, 地動加速度 と応答の片寄りの相関性を剛塑性モデルによって検討する。地動加 速度の片寄りの指標としては，図 2(a) では正負の最大值の比率を考

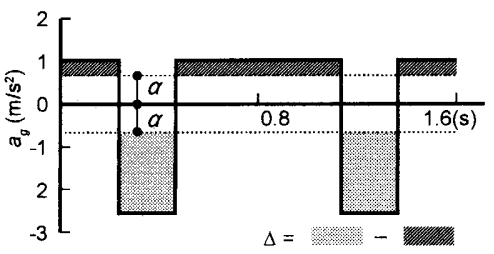

(a) $\Delta$ の定義 (A2.5)

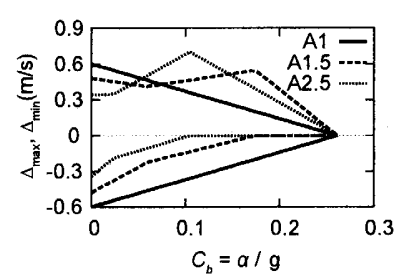

(b) $\Delta_{\max }, \Delta_{\min }-\alpha / \mathrm{g}$ の関係
図 8 入力地震動の片寄り

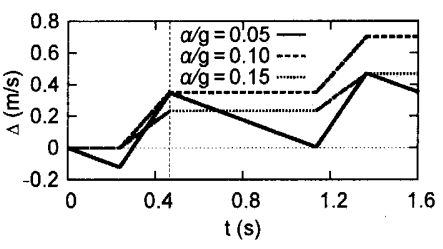

(a) $\Delta$

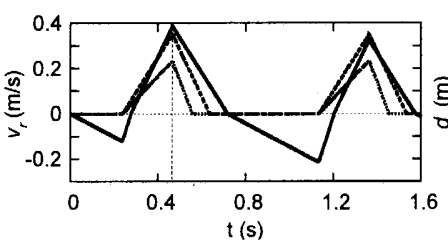

(c) 相対速度

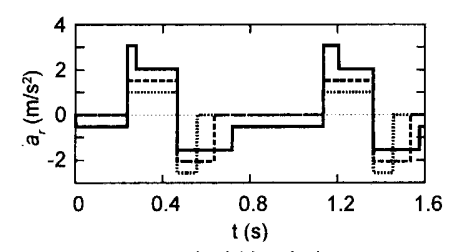

(b) 相対加速度
図 9 剛塑性 A2.5 時刻歴

えたが, 図 6(a) の様に質点の $C_{b}$ の変化により応答の片寄り方が変化 するため，本章では $C_{b}$ に対する指標を考える。

剛塑性モデルは, 地動加速度 $a_{\mathrm{g}}$ により生じる慣性力 $\left(=-m a_{\mathrm{g}}\right)$ が降 伏せん断力 $Q_{u}$ を超えると塑性化する ${ }^{9}$ 。図 8(a)に A2.5 の地動加速度 時刻歴を示すが, $\alpha=Q_{u} / m$ とすると, $\alpha$ と $a_{\mathrm{g}}$ の差 (図 8(a) ハッチ部分) が質点の応答の大部分を決定する。A2.5の地動について，この差の 積分値

$$
\Delta(t)=\int_{0}^{t}\left( \pm \alpha-a_{g}\right) d t
$$

ただし $\alpha$ の正負は $a_{\mathrm{g}}$ の符号に従う

が時刻とともに変動する様子を図9(a)に示す。gは重力加速度である。 $\alpha / \mathrm{g}=0.05$ のモデルでは正負両方向で $\alpha<\left|a_{\mathrm{g}}\right|$ となるため, $\Delta$ は増減 を繰り返す。 $\alpha / \mathrm{g}=0.10$ 及び 0.15 のモデルでは負方向のみで $\alpha<\left|a_{\mathrm{g}}\right|$ となるため, $\Delta$ は正方向に増えるのみである。さらに，質点の相対加 速度, 速度, 変位応答時刻歷を図 9(b) (d) に示す。図 9(a) と図 9(c) を比較すると, $\mathrm{t}=0.45 \mathrm{~s}$ までは両者がほぼ一致するが，それ以降， $\Delta$ が一定もしくは緩やかに低下するのに対し, 応答速度はゼロに向かっ て急激に減少する。これは, 質点の復元力により負方向の相対加速 度 (図9(b)) が生じるからである (詳しくは文献9)参照)。 $\Delta$ の時刻歴は, むしろ, 図 9(d) の変位時刻歴と相似している。つまり, 地動加速度 の片寄りが応答変位の片寄りを生じさせることが時刻歴でも証明さ れたと言える。ただし, 定量的に見ると, $\Delta$ の時刻歴と応答変位が完 全に比例関係にあるわけではない。例えば， $C_{b}=0.10$ の応答変位は $C_{b}=0.15$ の 1.8 倍に達するが, $\Delta$ は 1.4 倍にとどまる。

$\Delta$ の時刻歴に抢ける最大值と最小值を $\Delta_{\max }, \Delta_{\min }$ と呼ぶことにする。 地動 $\mathrm{A} 1, \mathrm{~A} 1.5, \mathrm{~A} 2.5$ について, 種々のベースシア係数 $C_{b}=\alpha / \mathrm{g}$ に対 応する $\Delta_{\max }, \Delta_{\min }$ を図 8(b) に示す。これも図6(a)(変位応答) との相 似性が高いが，完全に比例的ではない。両者の関係はフーリエスペ クトルと弾性応答スペクトルの関係に似ているように思われる。フー 
リエスペクトルは卓越周期が波の性質を直接的に表現するが，建物 の応答を知るには弾性応答スペクトルの方が有用である。なお，図 6(a)のグラフを「剛塑性応答スペクトル」と呼ぶことにする。弾塑性 応答スペクトルは減衰定数に応じて複数のグラフが存在するが, 剛 塑性応答スペクトルは一波につき一つしか存在しない。

\section{7. 実地震動を入力したときの応答の片寄り}

本章では, 図 2 に示した地震動のうち, 地動加速度の片寄り比率 が 2 を超えた 1992 年 Turkey 地震 Erzikan 記録 NS 成分 (ERZIKAN と 呼ぶ ) と, 片寄りの小さかった 1994 年 Northridge 地震 Jensen Filter Plant 記録 292 成分 (NORTHR と呼ぶ) を用いて応答解析を行う。剛 塑性 (RP), $T=0.2 \mathrm{~s}, 0.6 \mathrm{~s}$ の完全弾塑性 (EP) モデルに実地震動を入力 したときのベースシア係数 $C_{b}$ と正負の最大変位の関係を図 10 に示 す。(a)の ERZIKAN は全体的に負方向に大きく片寄った応答で，(b) の NORTHR は正負の片寄りの少ない応答となった。図 2(b) に示すよ うに, ERZIKAN は NORTHR よりも $0.2 \mathrm{~m} / \mathrm{s}$ 程度最大速度が小さいが, ほとんどの $C_{b}$ で ERZIKAN の変位の方が大きかった。そこで, 図 11 $に \Delta_{\max }, \Delta_{\min }$ と $\alpha / \mathrm{g}$ の関係を示す。例えば, $C_{b}=0.1$ で比較すると, NORTHR では $\Delta_{\max }$ と $\Delta_{\min }$ がほぼ等しいのに対して, ERZIKANでは $\Delta_{\max }$ が $0.05 \mathrm{~m} / \mathrm{s}, \Delta_{\min }$ が $-0.9 \mathrm{~m} / \mathrm{s}$ であり，極端に異なる。このような地 動加速度の片寄りが応答の片寄りの一因であったと推察される。

次に, $C_{b}=0.1$ の剛塑性 (実線) と完全弾塑性 $(T=0.6 \mathrm{~s})$ (一点鎖線 ) の時刻歷を図 12，13 に示す。また， $\Delta$ の時刻歷を図 12(c)，13(c)k 破線で示す。ただし，全継続時間のうち質点が最大変位となった付 近のみを拡大して示した。

まず，剛塑性モデルについて見ると，図 12 の ERZIKAN では，(1) の時刻まで地動加速度が小さく，質点はほとんど動かない。(1)-(2) の時刻間に非常に大きな正の地動加速度を受け (図 12(a)), 負の相対 加速度を生じ (図 12(b)), 相対速度を大幅に増加させる (図 12(c))。(2) の時刻から, 地動加速度は負になるが，(3) の時刻までは負方向に変 形を続ける。その後 (3)-(4) の区間で質点の変位は少し戻り，(4) の時 刻以降は動かない。このように, ERZIKAN は正方向の地動加速度の 方が負方向よりも大幅に大きいため, 質点の変位は負方向に片寄っ た。図 12(c) 破線の $\Delta$ は負方向に片寄っており，応答の片寄りと似た 傾向を示す。また, 完全弾塑性 $(T=0.6 \mathrm{~s})$ も, 同様に片寄りのある変 形となった。図 13 の NORTHRは, ERZIKAN と比べ, 図 13(a)の地 動加速度の片寄りが少なく，(c) 破線の $\Delta$ も正負の值を繰り返す。図 13(d)の相対変位時刻歴も， $\Delta$ と同様, 正負の值を繰り返した。

前章の単純波と同様に実地震動においても, 剛塑性, 完全弾塑性 モデルは地動加速度の片寄りの影響を受けやすく，地震動の最大加 速度・速度が小さくとも応答変位が大きくなる場合があることがわ かった。

\section{8. 剛塑性モデルの適用範囲}

完全弾塑性モデルの応答の片寄りが周期の増加によりどのように 変化するかを, 剛塑性モデルと比較する。完全弾塑性モデルの周期 $T$ を横軸にし，(a)ERZIKAN，(b)NORTHRを入力した時の最大変位, 最小変位をプロットしたグラフを図 14 に示す。 $T=0 \mathrm{~s}$ は剛塑性モデ ルの結果である。

(a)，(b) いずれもベースシア係数が小さい場合には，完全弾塑性モ

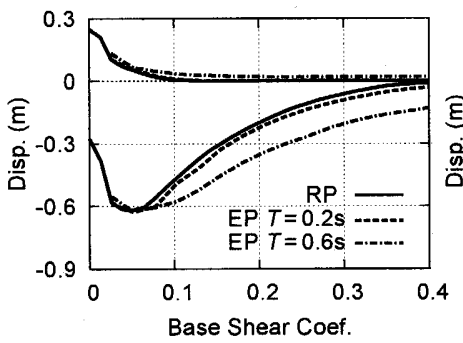

(a) ERZIKAN

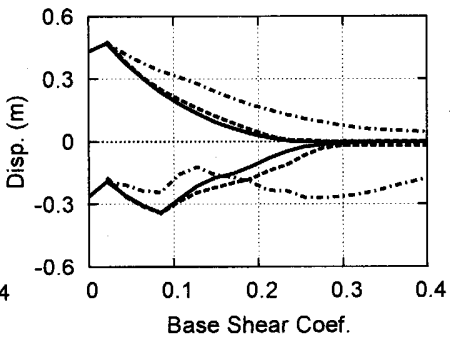

(b) NORTHR
図 10 剛塑性，完全弾塑性

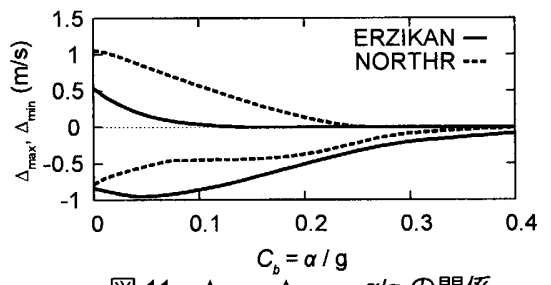

図 $11 \Delta_{\max }, \Delta_{\min }-\alpha / g$ の関係

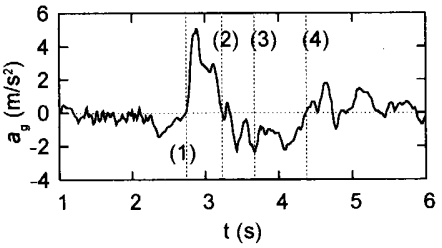

(a) 地動加速度

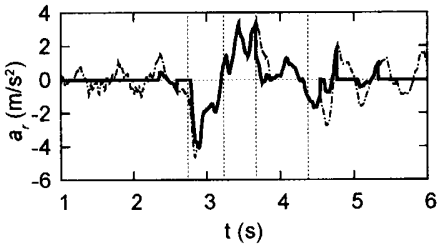

(b) 相対加速度

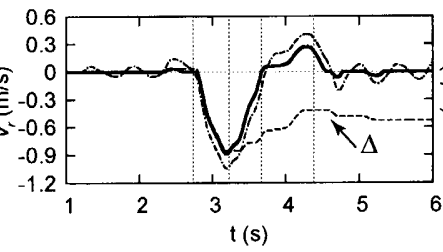

(c) 相対速度

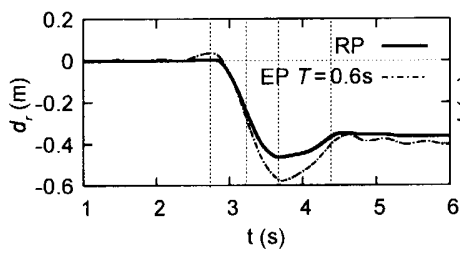

(d) 相対变位

図 12 ERZIKAN 時刻歴

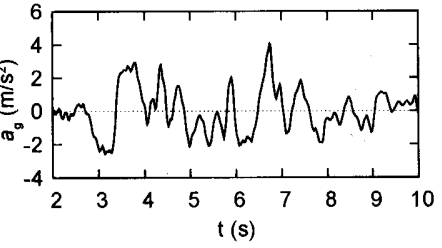

(a) 地動加速度

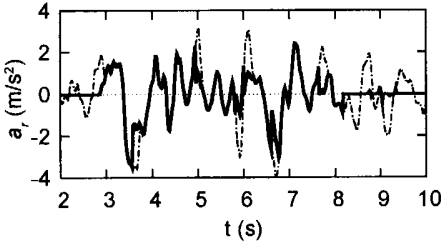

(b) 相対加速度

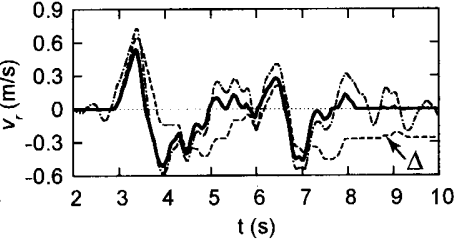

(c) 相対速度

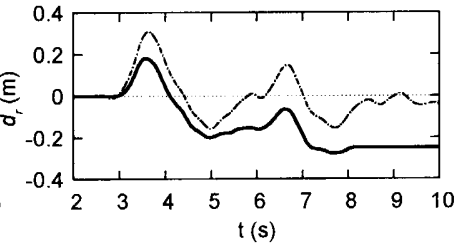

(d) 相対変位
図 13 NORTHR 時刻歴

デルの周期が変化した場合にも剛塑性モデルの応答とほぼ同じとな る。ベースシア係数が大きい場合には, 周期が増加するにつれ, 剛 塑性モデルの応答から離れていく。(a)の ERZIKAN では負方向に増 加し，(b)の NORTHR では正負両方向に変位が增加する。またべー スシア係数, 周期が大きいほど増加の傾きは大きくなった。他の実 地震動においても, ベースシア係数, 周期が大きくなるにつれ, 剛 塑性モデルの応答との違いが大きくなった。増加，減少の傾向は地 震動により異なるが，少なくともべースシア係数が小さく周期の小 
さい完全弾塑性モデルは剛塑性モデルの応答の大きさや片寄りとほ ぼ同じであった。従って，低層の免震建物，強度の低い鉄骨造建物 は剛塑性モデルによって大地震時の建物の変形の大きさや片寄りを 表すことができる。

\section{9. 剛塑性応答スペクトルの有効性}

加速度の片寄りと完全弾塑性モデルの応答の片寄りを比較する。 図 2 の実地震動のうち, $\mathrm{PGA}>5 \mathrm{~m} / \mathrm{s}^{2}$ かつ PGV $>0.5 \mathrm{~m} / \mathrm{s}$ である地震動 57 波の $\Delta_{\max }, \Delta_{\min }$ の絶対值の差を横軸に, 完全弾塑性モデル $(T=0.2 \mathrm{~s}$, $\left.C_{b}=0.2\right)$ の最大応答変位 $(\mathrm{MAX}(\mathrm{EP}))$, 最小応答変位 $(\mathrm{MIN}(\mathrm{EP}))$ の差 を縦軸にとったグラフを図 15(a)に示す。図中の実線は回帰直線であ る。

加速度の片寄り $(\Delta$ の片寄り) の増加に伴い, 応答変位の片寄りが 増加する傾向にある。しかしながら，両者は完全な比例関係ではな く，回帰直線から大きく離れた結果も存在する。そこで，回帰直線 から大きく離れた結果を中心に 4 波選び， $\Delta_{\min }, \Delta_{\max }$ と $\alpha / \mathrm{g}$ の関係を 図 16(a) に，剛塑性，完全弾塑性モデル $(T=0.2 \mathrm{~s}, 0.6 \mathrm{~s})$ のベースシア 係数 - 最大変位関係を図 16(b) (d) に示す。また, 4 波の詳細を表 1 に示す。

図 16(a)では，4 波とも全体的に負方向に片寄っており, 図 16(c) の完全弾塑性モデルの応答も同様である。しかしながら, 片寄りの 大きさや応答の大きさについては，両者は比例関係にない。図 16(a) では，TAK000よりも PCD164の方がわずかに負方向に片寄っている が, 図 16(c) では PCD164 はベースシア係数によっては, 変位が片寄 らず, $C_{b}=0.2$ 付近では TAK000よりも片寄りが小さくなった。 7 章 で示したように，地動加速度の片寄りは応答の片寄りに影響を与え ているが, 全ての地震動を対象とした場合には, 図8(a)のように地 動加速度の片寄りを見ているだけでは応答の片寄りを表現するのは 困難であることがわかった。

次に，図 16(b) 〜 (d) を比較すると，(c) の $T=0.2 \mathrm{~s}$ モデルと，(d) の $T=0.6 \mathrm{~s}$ モデルの $C_{b}$ が小さい範囲では, 各地震動のグラフは (b) の

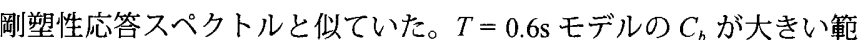
囲でも，剛塑性応答スペクトルを横に引き延ばしたようなグラフと なり，片寄りの傾向は似ているといえる。単純波だけでなく，実地 震動においても，剛塑性応答スペクトルと完全弾塑性モデルの応答 の片寄りは相似性が高かった。また，剛塑性モデルの最大応答変位 (MAX(RP)), 最小応答変位 $(\mathrm{MIN}(\mathrm{RP}))$ の差を横軸, 完全弾塑性モデル $(T$ $\left.=0.2 \mathrm{~s}, C_{b}=0.2\right)$ の最大応答変位, 最小応答変位の差を縦軸にとった グラフを図 15(b) に示す。両者はほぼ比例関係にあり，相関係数も図 15(a) の場合よりも高かった。従って, ある地動が完全弾塑性モデル の応答の片寄りを生じやすいかどうかを表現するには, 剛塑性応答 スペクトルを用いるのが有力である。

\section{9. まとめ}

初期周期が 0.6 秒以下でベースシア係数の小さい完全弾塑性系が非 常に強い地震動を受けるときの応答に関して次の結論を得た。

1. 地動速度の片寄りよりも地動加速度の片寄りの方が応答の片寄り に及ぼす影響が大きい。

2. 完全弾塑性モデルでは, 加速度が同程度で速度が小さい地動（従っ て Demand Spectrum も小さい地動）であっても，片寄りによって応

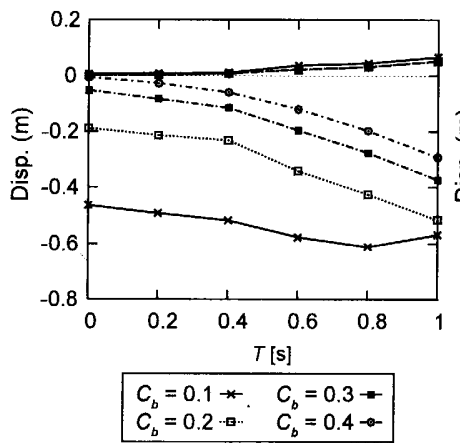

(a) ERZIKAN

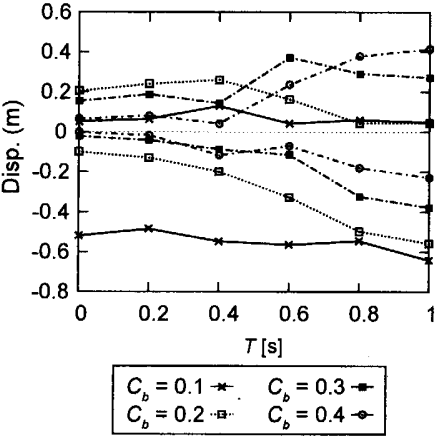

(b) NORTHR

図 14 周期をパラメータとした完全弾塑性モデルの片寄り

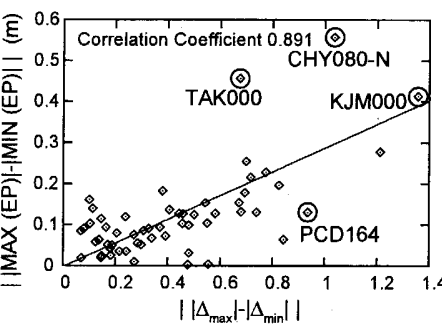

(a) $\Delta$ と完全弾塑性の片寄り

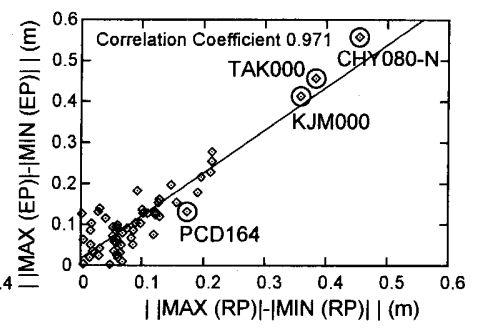

(b) 剛塑性と完全弾塑性の片寄り

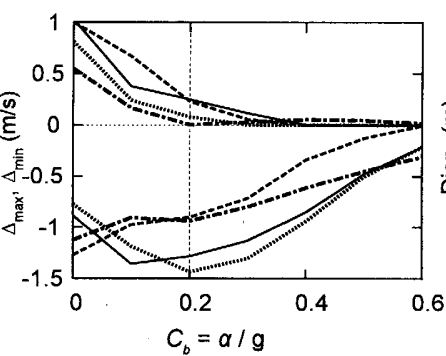

(a) $\Delta_{\max }, \Delta_{\min }-\alpha / g$ の関係

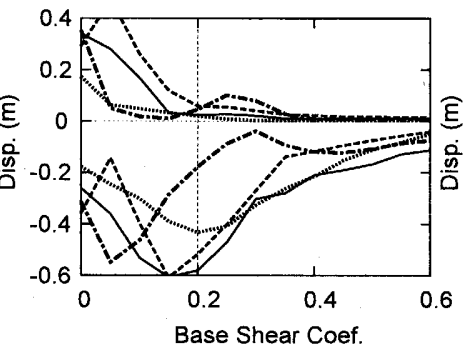

(c) 完全弾塑性モデル $(T=0.2 \mathrm{~s}) \quad$ (d) 完全弾塑性モデル $(T=0.6 \mathrm{~s})$ ベースシア係数一最大変位関係 ベースシア係数一最大変位関係 図 16 実地震動の応答の片寄り

表 1 図 16 で用いた入力地震動

\begin{tabular}{|c|c|c|c|c|}
\hline & Date/Earthquake & Record/Component & $\begin{array}{c}\text { PGA } \\
\left(\mathrm{m} / \mathrm{s}^{2}\right)\end{array}$ & $\begin{array}{c}\text { PGV } \\
(\mathrm{m} / \mathrm{s})\end{array}$ \\
\hline PCD164 & $1971 /$ San Fernando & SFERN/PCD164 & 12.26 & 1.13 \\
\hline KJM000 & $1995 /$ Kobe & KOBE/KJM000 & 8.21 & 0.81 \\
\hline TAK000 & $1995 /$ Kobe & KOBE/TAK000 & 6.11 & 1.27 \\
\hline CHY080-N & $1999 /$ Chi-Chi, Taiwan & CHICHI/CHY080-N & 9.02 & 1.02 \\
\hline
\end{tabular}


答がより大きくなる場合がある。

3. しかし, 図8(a) のように地動加速度の片寄りを見ているだけでは, 応答の片寄りを表現することは困難である。

4. ある地動が完全弾塑性モデルの応答の片寄りを生じやすいかどう かを表現するには，剛塑性応答スペクトル (剛塑性モデルのベース シア係数と最大応答変位の関係) を用いるのが有力である。 今後は，本論文の成果を，免震建物の設計法，低層鉄骨建物の耐 震診断, もしくは地震時の被害予測法に発展させたいと考えている。

\section{参考文献}

1) Freeman, S. A. : Prediction of response of concrete buildings to severe earthquake motion, Douglas McHenry Int. Symp. on Concrete and Concrete Struct., ACI SP-55, American Concrete Institute, Detroit, pp.589-605.1978

2) 平成 12 年 5 月 31 日建設省告示第 1457 号

3) ATC, Seismic evaluation and retrofit of concrete buildings, Vol.1, ATC-40, Applied
Technology Council, Redwood City, 1996

4) 秋山宏：建築物の耐震極限設計, 東京大学出版会, 1980.9

5) 向井智久，衣笠秀行，野村設郎：地震動を受ける RC 構造物の限界応答変形 量を保証するに必要な耐力算出法とその精度検証, 日本建築学会構造系論文 集, 第 532 号, pp.137-143.2000.6

6) 石岡拓, 和泉信之, 藤堂正喜, 千葉脩：限界耐力計算法における応答変形 の推定に関する考察, 構造工学論文集, Vol.51B, pp.189-196, 2005.3

7) 平成 17 年 6 月 28 日国土交通省告示第 631 号

8) 丸橋奈々子, J. L. D. コスタ, M. P.ニールセン, 市之瀬敏勝：剛塑性モデル を用いた地震応答の非対称性に関する基礎的研究, 日本建築学会構造系論文 集, 第 598 号, pp.75-81, 2005. 12

9) Costa, J.L.D. , Bento, R. , Levtchitch, V., Nielsen, M.P. : Simplified non-linear time-history analysis based on the Theory of Plasticity, Proceedings of the ERES 2005

10) PEER Strong Motion Database : http://peer.berkeley.edu/smcat/

(2006年 4 月 10 日原稿受理，2006年 7 月 21 日採用決定） 